\title{
Corporate Governance Attributes, Corporate Risk Disclosure and Sustainability Disclosure: Egyptian Case
}

\author{
Dr. Ahmed Mahmoud Ahmed Elbrashy \\ Accounting lecturer \\ Alzarka, Higher institute of computer science and business \\ administration \\ Email: A.ebrashey@za.edu.eg
}

\section{ABSTRACT:}

This study aims to analyze the impact of corporate governance on the both voluntary risk and sustainability disclosure. I use the corporate governance attributes that are represented on board size, board independence, CEO duality, directors' ownership, blockholders' ownership, ownership concentration, and the audit committee.

Using 100 firm year observations I found a positive association between the board independence and the dependent variables risk and sustainability disclosure, and positive association between directors' ownership and the dependent variable sustainability disclosure without any effect on the risk disclosure. Moreover, I found a negative relationship between CEO duality and blockholder ownership as predictors and the

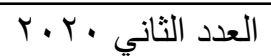


Corporate Governance Attributes, Corporate Risk Disclosure and Sustainability ...

dependent variables risk and sustainability disclosure. Furthermore, never have I found any relationship between the board size, ownership concentration and audit committee as predictors and the dependent variables risk and sustainability disclosure.

Key Words: Corporate Governance, Sustainability Disclosure, Risk Disclosure, agency theory.

\section{1- Introduction}

The development of societies leads more interest about sustainability, and considering it as a part of management policies by disclosing about it. Therefore, sustainability reporting becomes an important part of accounting and reporting practices in the both public and private sectors (Herzig and Schaltegger, 2006; Schaltegger and Burritt, 2006; Burritt and Schaltegger, 2010; Gray, 2010; Guidry and Patten, 2010; Adams, 2013; Cebrián et al., 2013; Windolph et al., 2014).

Sustainability reporting aims to link business strategy with the environmental and social performance of the firm, in addition to achieving the integration among the economic, environmental, and social dimensions of the firm, i.e. sustainability reporting enhance the informational side of the firm through using nonfinancial disclosure bedside the financial disclosure (Mook, 2006; Schaltegger and Wagner, 2006a,b). 
Corporate Governance Attributes, Corporate Risk Disclosure and Sustainability ...

Dr/ Ahmed Mahmoud Ahmed Elbrashy

Sustainability reporting stems from capital market interest about the financial and non-financial information required for all the investors in the investment decision making (Arnold et al., 2012). Capital markets interest about the sustainability reporting because of some factors related to the firm or the general contextual factors ((e.g. size or industry grouping for the firm, or economic, political or social context) (Adams, 2002). On the other side, the main goal of sustainability reporting is the shareholder wealth maximization through managing risks which may harm the firm reputation, especially if these risks were not financial (Adams and Whelan, 2009).

Consequently, the sustainability reporting is too related by risk disclosure, i.e. the risk disclosure is the fundamental complement for the sustainability disclosure, so risk disclosure became the most critical dimension for the disclosure policy, where the risky businesses may lead to risky investments. Reducing the investment risks for the investors require the financial statement include the relevant information related to the accurate risk assessment, which means eliminating the level of uncertainty about the future firm's cash flows and operating results as possible. The increased level of corporate risk disclosure leads to greater transparency and higher investor confidence in the firm market performance (Hassan, 2009, 2014; Abraham and Cox, 2007; Linsley and Lawrance, 2007; Linsley

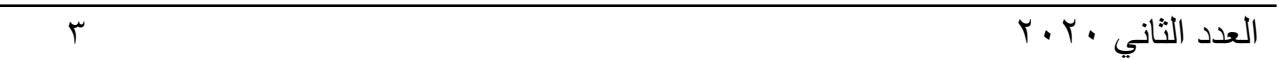


Corporate Governance Attributes, Corporate Risk Disclosure and Sustainability ...

and Shrives, 2006; Cabedo \& Tirado, 2004; Solomon et al., 2000; Schrand and Elliott, 1998; Meier et al., 1995).

On another vein, corporate governance attributes refers to the controlling way of the firm which depend on using rules, practices and processes system for determining the institutional arrangements, decision-making mechanisms, and organizational design (Lau et al., 2016; Garcia-Torea et al., 2016; Kolk, 2008; Gibson \& O'Donovan, 2007). The corporate governance attributes arose for solving the agency problems, so these attributes serve as an organizer for the relationship between the principal party and the agent party by motivating and monitoring the agent party decisions (Hashim et al., 2015).

Moreover, the main objective of both corporate governance and sustainability disclosure is to enhance corporate legitimacy. Corporate legitimacy means corporate ability to fulfill the external expectations of the investors in the context of social regulations, values, faith, and concepts (Suchman, 1995). In addition, the risk disclosure is the fundamental complement for the sustainability disclosure so it participates with the both corporate governance and sustainability disclosure in the main objective. There is no doubt that, corporate governance attributes and the both sustainability and risk disclosures are methods for enhancing the quality of nonfinancial information by achieving the legitimacy management (Jo \& Harjoto, 2012; Spitzeck, 
Corporate Governance Attributes, Corporate Risk Disclosure and Sustainability ...

2009). Consequently, disclosing about sustainability and risks may help in generation positive market responses, which enhance the legitimacy and mean also committing with the moral obligations (Mathews, 1995).

Based on the above, Corporate governance through its agreement with the both sustainability and risk disclosure in the main objective of legitimacy, I can expect that corporate governance attributes may be a great mechanism for strengthening the quality of the quality of nonfinancial disclosure. Consequently, I can embody the problem study of my research through the following questions: what is the effect of corporate governance attributes on the level of sustainability disclosure? And what influences corporate governance attributes on the level of risk disclosure?

In this study, I contribute to the literature by two ways: firstly, the prior research in the Egyptian environment was more interested by the corporate governance disclosure and its relationship with the other elements of sustainability disclosure (e.g. Samaha, et al., 2012; Samaha, 2010; Samaha \& Dahawy, 2010), but in my research I add the risk disclosure as a fundamental complement for the sustainability disclosure and I examine the effect of corporate governance attributes without the level of disclosure about corporate governance. Secondly, my sample depend on the firms included in the EGX 100 index 
Corporate Governance Attributes, Corporate Risk Disclosure and Sustainability ...

Dr/ Ahmed Mahmoud Ahmed Elbrashy

which is contain the most active firms in the Egyptian capital market which means possibility of generalization the results.

The remainder of this paper is organized as follows. Section 2 provides the literature review. Section 3 shows the Egyptian corporate governance. Section 4 discusses the corporate risk disclosure. Section 5 provides the practices of sustainability disclosure in Egypt. Section 6 shows the hypotheses development. Section 7 describes research methodology. Section 8 analyzes the empirical results. Section 8 contains the conclusion of research.

\section{2- Literature Review:}

A bulk of prior literature have shown the most influencing factors on the level of corporate risk disclosure, which are represented in firm share price (e.g. Uddin \& Hassan, 2011; Jorion, 2002; Linsmeier et al., 2002; Wong, 2000; Rajgopal, 1999; Schrand, 1997), firm size (e.g. Amran et al., 2009; Lopes \& Rodrigues, 2007; Linsley \& Shrives, 2006), ownership structure (e.g. Mokhtar \& Mellett, 2013; Abraham \& Cox, 2007) and director type (e.g. Oliveira et al., 2011; Abraham and Cox, 2007).

Another bulk of literature have analyzed the level of corporate risk disclosure in the emerging countries (e.g. Elkelish and Hassan, 2014; Hassan, 2009, 2014; Amran et al., 2009). On 
Corporate Governance Attributes, Corporate Risk Disclosure and Sustainability ...

the context of these literatures, Amran et al. (2009) Abraham \& Cox (2007) and Linsley \& Shrives (2006) examined the effect of firm-level characteristics on the level of corporate risk disclosure depending on the non-financial sections of annual reports, and all of them agree that both industry type and firm size were significant predictors of corporate risk disclosure. In the same vein, Elkelish and Hassan (2014) investigated the effect of organizational culture on the corporate risk disclosure.

Although the interest of the previous bulk of literature with the firm level characteristics as a predictor of the corporate risks disclosure, they totally neglected the corporate governance attributes and its impact on the corporate risk disclosure. So, in my research I extend this growing line of literature by examining the effect of corporate governance on the corporate risk disclosure

In this regard, corporate governance is the most controversial issue in the international financial environment (Majumder et al., 2017). Corporate governance became widely mechanism resulting from the separation of ownership and management of the company and work as a controlling system which safe all stakeholders and prevent the interest conflicts (Al Farooque and Ahulu, 2017; Majumder et al., 2017; Basuony et al., 2014; Dharmadasa et al., 2014; Ji et al., 2015; Mohamed et al., 2009; Donnelly and Mulcahy, 2008; Jamali et al., 2008). 
Corporate Governance Attributes, Corporate Risk Disclosure and Sustainability ...

In general, corporate governance attributes can be divided into two groups is ownership structure and board structure. For the ownership structure it is divided into directors', institutional, foreign and managerial ownership and ownership concentration, but for the board structure is tackled in terms of size, independence, diversity and CEO duality (Chief Executive Officer duality) (Dharmadasa et al., 2014; Azeem et al., 2013). Reducing the information asymmetry require more disclosure especially non-financial disclosure so sustainability disclosure has a great importance for all stakeholders and its effects on the business operations is increasingly demanded (Majumder et al., 2017; Azeem et al., 2013; Kolk, 2008)

Sustainability reporting stands for the relationship between the society and the firms; it establishes the accountability and responsibility about the results of the business operations and its effect on the society (Klettner et al., 2014; Kabir \& Akinnusi, 2012; Kolk, 2008). Where the sustainability related to the usage of clean and renewable sources of energy and the development of socially responsible products and services, in addition the fair treatment of employees (Tang et al. 2015; Mann et al. 2014; Rao, et al., 2012).

Regarding to the relationship between sustainability reporting and the corporate governance a bulk of literature agreed that a positive relationship between the corporate governance structure 
Corporate Governance Attributes, Corporate Risk Disclosure and Sustainability ...

and sustainability reporting, because corporate governance attributes can be commit the firm by non-financial disclosure related to environmental and social issues (e.g.Adel, et al., 2019; Adnan, et al., 2018; Eberhardt-Toth, 2017; Fuente et al., 2017).

Based on the previous literature, I found that majority of these literatures focused on the corporate governance disclosure and little of them analyzed the relationship between the corporate governance attributes and sustainability reporting but it does not analyze all attributes, in addition analyzing the relationship between the corporate governance and the corporate risk disclosure is neglected. Consequently, I can fill this gap through my research by extending this line of literature by using all corporate governance attributes available in the Egyptian environment and its effect on the both sustainability and risk disclosure.

\section{3- Egyptian corporate governance}

Corporate governance is an important modern issue and has a vital role in the capital markets in the developing countries such as Egypt. It can achieve the sustainability for the firms which lead to more stable and efficient capital market. Besides, the corporate governance can safeguard the shareholders' wealth and meet the needs of the other stakeholders about the non-financial information. In addition, it encourages the development of the 
Corporate Governance Attributes, Corporate Risk Disclosure and Sustainability ...

competitive capabilities which guarantee the financing sources of the firms and generating more profits (Samaha, et al., 2012).

In Egypt, the capital market tend to lay down the corporate governance rules for the firms from the fiscal year 2005, and to keep up with evolution cared about performing many adjustments on these rules for developing it in the international economic and financial environment. In the context, the Egyptian capital market issued the Egyptian guide for corporate governance rules in 2011 for including all adjustments in the international environment. But with the development in the business environment appeared the international interests about sustainability disclosure as one of the most important requirements of corporate governance rules, which is lead to issue new guide of governance from the Egyptian Institute of Directors (third edition) on 26 july 2016.

This Egyptian guide for the corporate governance rules is issued for enhancing the level of confidence of foreign portfolio investors in the Egyptian capital market. The Egyptian guide for the corporate governance rules prepared accordance with the regulations of Organization for Economic Cooperation and Development (OECD) and reviewed by the International Finance Corporation (IFC) and the International Bank.

This guide aim to protect the rights of all stakeholders through enhancing the disclosure practices and transparency, in

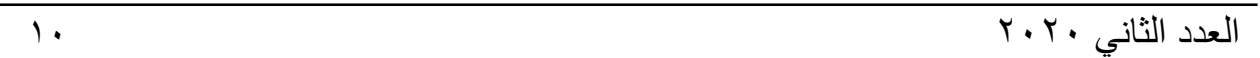


Corporate Governance Attributes, Corporate Risk Disclosure and Sustainability ...

addition this guide helping in organizing the relationships among the shareholders, board of directors and management, but the compliance for these rules is not mandatory. Consequently, the Egyptian stock market inserted some indexes which can measure performance of the firms represented in: EGX 30, EGX 70, EGX 100 , and all of the companies listed in these indexes refer to the most trading stocks in an effective manner in the Egyptian stock market, so these companies listed in the indexes refer to the most companies committed by the laws and the corporate governance rules.

As a result of non-compliance to the corporate governance rules by a mandatory way, appear the neglecting of these rules by the majority of firms that are outside the Egyptian indexes. Consequently, key policies on risk management, internal control and audit processes, and succession planning are often absent. Therefore, it was a gap between the existence of the Egyptian corporate governance rules guide and the compliance to this guide, so it is important filling this gap by following these steps (Samaha, et al., 2012):

- Forcing companies by applying the Egyptian corporate governance rules guide and explain the causes of not compliance if exist.

- Continuous improvement in the Egyptian corporate governance rules guide to meet the international 
Corporate Governance Attributes, Corporate Risk Disclosure and Sustainability ...

Dr/ Ahmed Mahmoud Ahmed Elbrashy

requirements and be applicable in the Egyptian environment.

- Providing the training programs required for achieving the effective application for the Egyptian corporate governance rules guide.

\section{4- Corporate risk disclosure:}

Corporate risk refers to the internal and external factors that affect the corporation's wealth, challenges, opportunities and threats (Cabedo \& Tirado, 2004). So, risk is the main determinant of the potential loss or profit in the corporation wealth, it is referring to the interaction between the internal and external factors that may restrict the firm opportunities. In addition, risk refers to any hazard, danger, harm, threat or exposure may effect on the firm future (Linsley \& Shrives, 2006).

Given the above risk definition, the risk reporting is defined as reporting about the events surrounding the company that may increase or decrease the value of the firm as well as risk reporting include the available means for minimizing the risks surrounding the company (Hassan, 2009). In this regard, I follow Abdallah, et al. (2015) by using their index for corporate risk disclosure, because it include 45 types of risks that may be existed and applicable for all firms included in the EGX100 as shown in Appendix A. 
Corporate Governance Attributes, Corporate Risk Disclosure and Sustainability ...

\section{5- Sustainability Disclosure practices in Egypt;}

Actually, Sustainability definition is depending on the World Commission on Environment and Development, which establishes the comprehensive justice for all stakeholders. Consequently, sustainability depends on the ability to meet the present owners' needs without harming the future generations (World Commission on Environment and Development, 1987). For achievement the sustainability requirements the firms mustn't neglect the environmental and social dimensions and its effect on the owners and all stakeholders including the society (Lozano \& Huisingh, 2011; Dyllick \& Hockerts, 2002). In addition, numerous studies (e.g. Murphy and McGrath, 2013; Lozano \& Huisingh, 2011) added new dimensions for the sustainability reporting like time and corporate environmental and social governance. As a result of development corporate governance the sustainability reporting become so important concept in the accounting environment (Hahn \& Kühnen, 2013).

In Egypt, the notion of development the sustainability reporting depended on the adoption of some strategies that meet the needs of the owners without conflict with the protection of human and natural resources. Consequently, the Egyptian stock exchange launched the Egyptian index of sustainability reporting on 23 march 2010 with the cooperation between the standard and 
Corporate Governance Attributes, Corporate Risk Disclosure and Sustainability ...

poor's corporation and the Egyptian Institute of Directors. This index considers the first index in the arab world and the second worldwide, it classify the performance of listed companies in the Egyptian stock exchange by ranked them according to the commitment to the corporate governance rules and its interest by the environmental and social dimensions (The Egyptian Guide For Sustainability Reporting, 2016). In this regard I follow the Egyptian index for sustainability reporting as shown in Appendix B.

\section{6- Hypotheses Development:}

Corporate governance attributes can explain the level of voluntary disclosure from the perspective of agency theory. Consequently, I will examine the effect of corporate governance attributes on the level of voluntary disclosure related to risk and sustainability. Based on the prior literature the corporate governance attributes related to the both board of director and ownership structure are the most attributes related to increase the level of voluntary disclosure. To my best knowledge a little studies interested in the detailed analysis between the corporate governance attributes and the voluntary disclosure of the both risk and sustainability, in particular I have found no studies in the Egyptian accounting environment interested in this relationship.

Accordingly, I develop my research hypotheses based on corporate governance attributes related to board characteristics, 
Corporate Governance Attributes, Corporate Risk Disclosure and Sustainability ...

Dr/ Ahmed Mahmoud Ahmed Elbrashy

ownership structure and the existence of audit committees and its effect on the level of both voluntary sustainability and risk disclosure as follow.

\section{1: Board characteristics and the voluntary disclosure of both sustainability and risk:}

\subsection{1: Board independence:}

From the agency theory perspective, the independence of board of directors can be guaranteed when the directors elected by the shareholders and it's preferred to be outsiders or independent directors and are not from the executive directors (Chau \& Leung, 2006; Haniffa \& Cooke, 2005; Weir \& Laing, 2003). This independence can overcome the conflict of interest between the owners and the managers, which is mean increasing quality of monitoring on the management, thus decreasing the probability of fraud on the financial statements, and meet the needs of large set of stakeholders (Majumder et al., 2017). Accordingly, the quality of financial statements may be improved and may exist the probability of making long term practices of disclosures and reporting including added value practices such as sustainability disclosure and risk disclosure and many other kinds of disclosure (Cheng \& Courtenay, 2006; Ibrahim et al., 2003). Generally, a great bulk of literature agreed that board independence improve the corporate disclosure (Mohamed et al., 2017; Majumder et al., 2017; Jizi et al., 2014; Donnelly and 
Corporate Governance Attributes, Corporate Risk Disclosure and Sustainability ...

Dr/ Ahmed Mahmoud Ahmed Elbrashy

Mulcahy, 2008; Cheng and Courtenay, 2006; Leung and Horwitz, 2004).

In contrast, numerous researchers agree that board independence has a negative impact on the voluntary disclosure because the board will not be interested by proving their legitimacy, where they are already independence so they will have no interest in fraud (Barako et al., 2006; Gul and Leung, 2004). On the other hand, some of researchers did not find any significant relationship between board independence and the voluntary disclosure (e.g. Amran et al. 2014; Lan et al., 2013; Michelon \& Parbonetti, 2012; Ho \& Wong, 2001).

On Egypt, Samaha \& Dahawy (2010 and 2011) Ezat \& ElMasry (2008) found a positive relationship between board independence and the voluntary disclosure. So I can develop my first hypothesis in the alternative form as follow:

H1: there is a significant positive association between board independence and the voluntary disclosure of both sustainability and risk.

\subsection{2: Board size:}

According to agency theory, greater size of the board leads to higher capacity in monitoring power of the board and increase its ability to make strategic decisions (Hussainey \& Wang, 2010). Moreover, greater board sizes mean higher expertise diversity 
Corporate Governance Attributes, Corporate Risk Disclosure and Sustainability ...

especially in the financial reporting (Mohamed et al., 2013; Gandía, 2008; Laksmana, 2008). Consequently, the greater board size may lead to decreasing earnings management and increasing the voluntary disclosure (Majumder et al., 2017; Jizi et al., 2014; Rao et al., 2012; Laksmana, 2008; Barako et al., 2006; Cheng \& Courtenay, 2006). In contrast, some literatures found that large board size lead to poor communication, thus time consumption in making decisions in addition achieving power to the CEOs for protecting themselves (Donnelly \& Mulcahy, 2008). On the other side, Lakhal (2005) found that smaller board size means more powerful for monitoring and replacing the CEOs, so the negative relationship between the board size and voluntary disclosure can be found. Other researchers did not find any significant relationship between the board size and the voluntary disclosure (Amran et al., 2014; Sartawi et al., 2014; Evans, 2004; Lakhal, 2005; Willekens, et al., 2005).

On Egypt, the significant positive relationship between the board size and the voluntary disclosure are found Ezat and ElMasry (2008). So, IU can develop my second hypothesis on the alternative form as follow:

H2: there is a significant positive association between board size and the voluntary disclosure of both sustainability and risk. 
Corporate Governance Attributes, Corporate Risk Disclosure and Sustainability ...

Dr/ Ahmed Mahmoud Ahmed Elbrashy

\subsection{3: CEO Duality:}

From the agency theory perspective, CEO duality refers to the existence of CEO on the board of directors; this duality diminishes the board independence hence decreasing the tendency about the voluntary disclosure (Donnelly \& Mulcahy, 2008). Accordingly, CEO duality increases the agency costs and the chance for earnings management, so it also can decrease the level of voluntary disclosure (Michelon \& Parbonetti, 2012; Gul \& Leung, 2004). On the other side, Jizi et al. (2014) investigated that CEO duality positively effect on the sustainability reporting because of their powerful engagement in addition they have more fear of losing their positions and the increased pressure from the shareholders. But in the same context, other researchers haven't found any relation between the CEO duality and the voluntary disclosure (Majumder et al., 2017; Cheng and Courtenay, 2006; Barako et al., 2006; Eng and Mak, 2003; Haniffa and Cooke, 2002; Ho and Wong, 2001). Consequently, the results about the results related to the relationship between the CEO duality and the voluntary disclosure are mixed.

On Egypt, Ezat and El-Masry (2008) found a negative relationship between the CEO Duality and the voluntary disclosures, so I can develop my third hypothesis in the alternative form as follow: 
Corporate Governance Attributes, Corporate Risk Disclosure and Sustainability ...

Dr/ Ahmed Mahmoud Ahmed Elbrashy

H3: there is a significant negative association between CEO duality and the voluntary disclosure of both sustainability and risk.

\section{2: Ownership structure and the voluntary disclosure of both sustainability and risk: \\ 6.2.1: Directors' ownership:}

Directors' ownership refers to the partial ownership of the directors on the company which leads to Compatibility of interests between directors and shareholders so they will not manage earnings and they will be interested in the quality of disclosure level, moreover they will be enthused in increasing the firm value and its shareholders' wealth as well as increasing the level of voluntary disclosure (Juhmani, 2013). In this context, some researchers agree that there is a positive relationship between the directors' ownership and the voluntary disclosure (Leung and Horwitz, 2004; Nasir and Abdullah, 2004; Nagar, et al., 2003). On the other hand, the negative relationship has also been found by numerous studies (e.g. Majumder, et al., 2017; Ghazali, 2007; Eng and Mak, 2003).

On Egypt, Samaha and Dahawy (2011) revealed a negative relationship between the directors' ownership and the voluntary disclosures, so I set my fourth hypothesis in the alternative form as follow: 
Corporate Governance Attributes, Corporate Risk Disclosure and Sustainability ...

H4: there is a significant negative association between directors' ownership and the voluntary disclosure of both sustainability and risk.

\subsection{2: Block holder ownership}

Block holders are is the owner of a large block of a company's shares and/or bonds. In terms of shareholding, these owners are often able to influence the company with the voting rights awarded with their holdings. In this regard some researchers found a negative association between the block holder ownership and voluntary disclosure (e.g. Schadewitz \& Blevins, 1998; Mitchell, et al., 1995; McKinnon \& Dalimunthe, 1993) while the positive association has also been found because the block holders in this case have limited access to information about the company (Marston and Polei, 2004; Haniffa and Cooke, 2002). Therefore, ownership dispersion leads to lower information asymmetry by increasing the disclosure level for providing the investors by the information needs.

On Egypt, Samaha \& Dahawy (2010 \& 2011) revealed a negative relation between the block holder ownership and voluntary disclosure, so I can set my fifth hypothesis in the alternative form as follow: 
Corporate Governance Attributes, Corporate Risk Disclosure and Sustainability ...

H5: there is a significant negative association between block holders' ownership and the voluntary disclosure of both sustainability and risk.

\subsection{3: Ownership concentration:}

Ownership dispersion leads to more information asymmetric between management and the shareholders, so higher number of shareholders greater agency costs and reducing these costs require more voluntary disclosure (Garcia-Meca and SanchezBallestabes, 2010). In this regard, numerous studies found a positive relationship between the ownership dispersion and the voluntary disclosure, this means negative relationship between the ownership concentration and the voluntary disclosure (Chau \& Gray, 2002; Malone, et al., 1993; Cooke, 1991).

On Egypt, Samaha \& Dahawy (2010 \& 2011) didnnot find any relationship between the ownership concentration and the voluntary disclosure, so I can develop my sixth hypothesis in the null form as follow:

H6: there is no relationship between the ownership concentration and the voluntary disclosure of both sustainability and risk.

\section{3: Audit committee and the voluntary disclosure of both sustainability and risk:}


Corporate Governance Attributes, Corporate Risk Disclosure and Sustainability ...

Audit committee is a voluntary mechanism which helps in improving the quality of information flow between principal and agents (Bradbury, 1990). Responding to the financial scandal in the late of the 1980s and 1990s increased the interest about audit committees in the firms all over the world (Mangena \& Tauringana, 2008). From the prospective of agency theory audit committees is an innovated mechanism for minimizing the agency costs and became an important mechanism for monitoring the internal control by the board of directors (Collier, 1993). Therefore, audit committees reinforce the information disclosure engagement (Barako et al., 2006; Forker, 1992)

On Egypt, Samaha \& Dahawy (2010 \& 2011) revealed that no relationship between audit committee existence and the the voluntary disclosure, so I can set my seventh hypothesis in the null form as follow:

H7: there is no relationship between the audit committee existence and the voluntary disclosure of both sustainability and risk.

\section{7- Research Methodology:}

\section{1: Data and sampling:}

The population study represented in all firms listed on the Egyptian stock exchange. In the Egyptian stock exchange there are three main indexes are EGX30, EGX70, and EGX 100 and 
Corporate Governance Attributes, Corporate Risk Disclosure and Sustainability ...

determine the most active traded firms in the stock market. These indexes evaluate the performance of the listed companies and express the practices of the exchange for the listed companies. Consequently, my sample study is the 100 companies listed on the EGX 100 for the year ended 2019. I use the manually content analysis technique for measuring the disclosure level of risk and sustainability in the annual reports and websites of the companies.

\section{2: Model specification and variable measurement:}

Testing the relationship between corporate governance attributes and the voluntary disclosure level of both sustainability and risk in Egypt, first S\&P/EGX ESG index is the measurement tool for the sustainability disclosure level by scoring the weights to each item included in the index by giving the item a score of 1 in the case of disclosure and 0 otherwise. Second, I follow Abdallah, et al. (2015) index in measuring the risk disclosure level by the same way of measuring the disclosure level of sustainability. Third, all the independent variables of my research limited to board independence, board size, CEO duality, directors' ownership, block holders' ownership, ownership concentration, and the audit committee.

Moreover, numerous studies revealed that the existence of Big-4 audit firms lead to enhancing the level of voluntary disclosure (e.g. Chau \& Gray, 2010; Amran \& Devi, 2008; 
Corporate Governance Attributes, Corporate Risk Disclosure and Sustainability ...

Huafang \& Jianguo, 2007; Haniffa \& Cooke, 2005; Gul \& Leung, 2004), while the existence listing status of subsidiaries increase the level of the voluntary disclosure practices (Webb et al., 2008; Chapple and Moon2005), as well as larger firms have a higher levels of voluntary disclosure (Owen, 2007; KPMG, 2005; Kolk, 2003). Consequently, I control the effects of Big-4 audit firms, listing status of subsidiaries, and size on the dependent variable related to sustainability disclosure level. On another vein, risk disclosure may be affected by some factors related to the financial position, these factors are leverage, reserves, and the finance sector of the firm (Abdallah, et al., 2015; Lopes and Rodrigues, 2007). Consequently, I control the effects of these variables on the dependent variable related to risk disclosure level. Accordingly, I use the two following multiple regression models:

$\mathrm{SDL}=\beta 0+\beta 1 \mathrm{~B}$.size $+\beta 2 \mathrm{~B}$.independence $+\beta 3 \mathrm{CEO}$ duality + $\beta 4 \mathrm{D}$.Own $+\beta 5 \mathrm{BL}$.Own $+\beta 6 \mathrm{C}$.Own $+\beta 7 \mathrm{~A}$.Com $+\beta 8 \mathrm{Big}-$ $4+\beta 9 \mathrm{LS}+\beta 10 \log$ size

$\mathrm{RDL}=\beta 0+\beta 1 \mathrm{~B} \cdot$ size $+\beta 2 \mathrm{~B}$.independence $+\beta 3 \mathrm{CEO}$ duality + $\beta 4 \mathrm{D}$.Own $+\beta 5 \mathrm{BL}$.Own $+\beta 6 \mathrm{C}$.Own $+\beta 7 \mathrm{~A}$. Com $+\beta 8 \mathrm{Lev}$ $+\beta 9$ reserves $+\beta 10 \mathrm{FNONF}(2)$

All variables inserted in the two above models are shown in the table No.1 which presents the definition of all variables, how 
Corporate Governance Attributes, Corporate Risk Disclosure and Sustainability ...

to measure, the predicted sign of independent variables, and the source of information for each variable.

Table No.1: Variables definition

\begin{tabular}{|c|c|c|c|}
\hline $\begin{array}{l}\text { Variable } \\
\text { symbol }\end{array}$ & variable full name & how to measure & $\begin{array}{l}\text { predicted } \\
\text { sign }\end{array}$ \\
\hline
\end{tabular}

First: Dependent Variables:

SDL

Sustainability

Disclosure Level

RDL
Risk Disclosure

Level
Percentage of the total disclosed items in the index

Percentage of the total disclosed items in the index

Second: Independent Variables:
B.size
Board Size
B.indepe
Board Independence
CEO duality
CEO duality
D.Own
BL.Own
C.Own

A.Com Audit Committee

Board members number

Number of independent directors on board/total board size

Dummy variable which is take

1 in the case of CEO exist as a member in the board and 0 otherwise

Percentage of shares owned by directors

Percentage of shares owned by blockholders

Percentage number of the shares owned by the shareholders

Dummy variable which is take 1 in the case of existence audit committee and 0 otherwise 
Corporate Governance Attributes, Corporate Risk Disclosure and Sustainability ...

Dr/ Ahmed Mahmoud Ahmed Elbrashy

Third: Control Variables:

\begin{tabular}{|c|c|c|}
\hline Big-4 & $\begin{array}{l}\text { Big-4 audit firm } \\
\text { existence }\end{array}$ & $\begin{array}{l}\text { Dummy variable which is take } \\
1 \text { in the case of existence Big- } \\
4 \text { audit firms and } 0 \text { otherwise }\end{array}$ \\
\hline LS & $\begin{array}{l}\text { List Status of } \\
\text { Subsidiaries }\end{array}$ & $\begin{array}{l}\text { Dummy variable which is take } \\
1 \text { in the case of existence } \\
\text { subsidiaries and } 0 \text { otherwise }\end{array}$ \\
\hline log size & Size Logarithm & $\begin{array}{l}\text { Logarithm of total market } \\
\text { value of the firm }\end{array}$ \\
\hline Lev & Leverage & $\begin{array}{c}\text { Total debt devided by the } \\
\text { owners' equity }\end{array}$ \\
\hline reserves & $\begin{array}{l}\text { Legal Reserves } \\
\text { Volume }\end{array}$ & The amount of legal reserves \\
\hline YFRS & $\begin{array}{l}\text { Application Years } \\
\text { of International } \\
\text { Financial Reporting }\end{array}$ & $\begin{array}{l}\text { Number of years that IFRS } \\
\text { was implemented }\end{array}$ \\
\hline FNONF & $\begin{array}{l}\text { Firms in the } \\
\text { Financial Sectors }\end{array}$ & $\begin{array}{l}\text { Dummy variable which is take } \\
1 \text { if the firm is in the finance } \\
\text { sector and } 0 \text { otherwise }\end{array}$ \\
\hline
\end{tabular}

\section{8- Empirical results:}

\section{1: Descriptive statistics:}

The descriptive statistics for all variables of my research are presented in the table No. 2. For the risk disclosure index includes 45 items divided into 7 groups, whereas the sustainability disclosure index in my research includes 143 items related to social, environmental and governmental issues. These indexes are shown in details in Appendix A\&B respectively. 
Corporate Governance Attributes, Corporate Risk Disclosure and Sustainability ...

Based on the results presented in the table No.2 it is clear that the mean of sustainability disclosure level is $31 \%$ which means that compliance to the sustainability disclosure index is so weak in the Egyptian environment, in addition the mean of risk disclosure according to my index is $27 \%$ which also means that commitment by risk voluntary disclosure is so weak. Besides, the mean of board size is 7.78 members and the mean of board independence is $69 \%$, so I conclude that my sample distinguished by a high level of board independence. Moreover, the mean of CEO duality is $40 \%$ which indicates that the majority of my sample adheres to the separation of duties. From the ownership perspective, I found the mean of directors' ownership, Blockholders' ownership and ownership concentration are 30\%, $43 \%$ and $42 \%$ respectively, which indicates that my sample is not suffer from concentration.

Table No.2: Descriptive statistics

\begin{tabular}{|c|c|c|c|c|c|}
\hline Variables & $\mathrm{N}$ & Minimum & Maximum & Mean & Std. Deviation \\
\hline SDL & 100 & 0.17 & 0.72 & 0.31 & 0.12 \\
RDL & 100 & 0.07 & 0.56 & 0.27 & 0.09 \\
B.size & 100 & 2.00 & 16.00 & 7.78 & 2.70 \\
B.independence & 100 & 0.00 & 1.00 & 0.69 & 0.21 \\
CEOduality & 100 & 0.00 & 1.00 & 0.40 & 0.49 \\
D.Own & 100 & 0.00 & 0.97 & 0.30 & 0.24 \\
BL.Own & 100 & 0.00 & 1.00 & 0.43 & 0.25 \\
C.Own & 100 & 0.02 & 0.95 & 0.42 & 0.24 \\
A.Com & 100 & 0.00 & 1.00 & 0.40 & 0.49 \\
Big4 & 100 & 0.00 & 1.00 & 0.59 & 0.49
\end{tabular}


Corporate Governance Attributes, Corporate Risk Disclosure and Sustainability ...

Dr/ Ahmed Mahmoud Ahmed Elbrashy

\begin{tabular}{|c|c|c|c|c|c|}
\hline LS & 100 & 0.00 & 1.00 & 0.38 & 0.49 \\
Logsize & 100 & 3.56 & 10.59 & 8.48 & 1.08 \\
Lev & 100 & -11.41 & 21.67 & 1.53 & 3.19 \\
reserves & 100 & 209619 & 24644672865 & 1409830721 & 4043255232 \\
YFRS & 100 & 3.00 & 5.00 & 3.26 & 0.68 \\
FNONF & 100 & 0.00 & 1.00 & 0.13 & 0.34 \\
\hline
\end{tabular}

Accordingly, my sample is consistent with numerous studies (e.g. Samaha, et al., 2010, 2011, 2012; Ho \& Wong, 2001), as well as the prior literature in Egypt indicates that analysts cannot get the majority of information related to the risk and sustainability disclosure from the annual reports because of the disclosure in this case is voluntary, so the most of my sample doesn't abide by achieving high disclosure levels of risk and sustainability. Consequently, I conclude the importance of risk and sustainability disclosure in mandatory form in the Egyptian case.

\section{2: Correlation analysis:}

The correlation matrix illustrates a positive relationship between board size, board independence and directors' ownership as an independent variables and the voluntary disclosure of the sustainability and risk as a dependent variables. On another vein, there is a negative relationship between the blockholders' ownership and ownership concentration as an independent variables and the voluntary disclosure of the sustainability and risk as a dependent variables. 
Corporate Governance Attributes, Corporate Risk Disclosure and Sustainability ...

Table No.3: Pearson Correlation Matrix

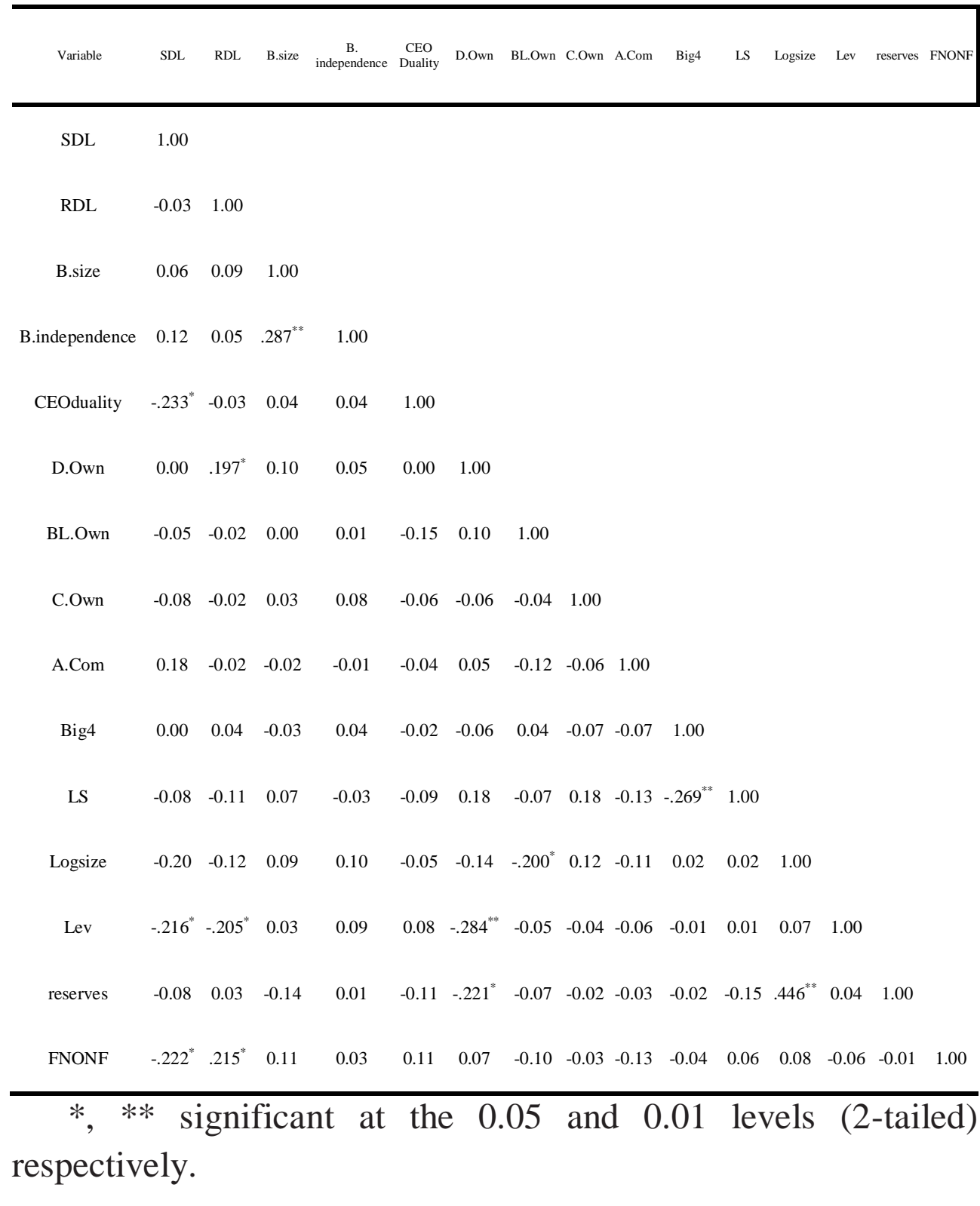

rq

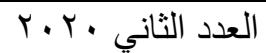


Corporate Governance Attributes, Corporate Risk Disclosure and Sustainability ...

Based on the above results in the matrix illustrated that hypotheses of my research are supported in an initial form, but I cannot ensure the validity of relationships in the hypotheses even conducting the regression analysis. Moreover the matrix clarify that I haven't absolutely suffer from the multicollinearity problems.

\section{3: Results of regression analysis:}

The results of regression analysis is shown in table No.4, and it illustrate in panel A that the coefficients of the board independence and the directors' ownership are significant and have a positive signal which means the existence of positive association between the board independence and the directors' ownership as predictors and the voluntary sustainability disclosure as a dependent variable. On the other side, the coefficients of the CEO duality and the blockholders' ownership as predictors are significant and have a negative signal, which indicates a negative association between the CEO duality and the blockholders' ownership and the voluntary sustainability disclosure. For the board size, ownership concentration and audit committee the coefficient are statistically in significant. Moreover the model has an explanatory power $68.60 \%$ and it is a good percentage compared to its counterparts in the prior literature (e.g. Samaha, et al., 2012; Samaha \& Dahawy, 2010, 2011; Samaha, 2010). 
Corporate Governance Attributes, Corporate Risk Disclosure and Sustainability ...

In table No.4 Panel B, the coefficient of board independence is statistically significant and has a positive signal, which indicates a positive association between the board independence as a predictor and the voluntary risk disclosure as a dependent variable. Furthermore, the coefficients of the CEO duality and BL.own are statistically significant and have a negative single which means a negative association between the CEO duality and BL.own as a predictors and the voluntary risk disclosure as a dependent variable. Moreover the model has an explanatory power $87.40 \%$ and it is so high compared to its counterparts in the prior literature (e.g. Samaha, et al., 2012; Samaha \& Dahawy, 2010, 2011; Samaha, 2010). 
Corporate Governance Attributes, Corporate Risk Disclosure and Sustainability ... Dr/ Ahmed Mahmoud Ahmed Elbrashy

Table No.4: Regression Results

\begin{tabular}{|c|c|c|c|c|c|}
\hline \multirow{3}{*}{ Variable } & \multirow{3}{*}{ Predicted Sign } & \multicolumn{2}{|c|}{ Panel A } & \multicolumn{2}{|c|}{ Panel B } \\
\hline & & \multicolumn{2}{|c|}{ Sustainability Disclosure } & \multicolumn{2}{|c|}{ Risk Disclosure } \\
\hline & & Estimate & t-statistic & Estimate & t-statistic \\
\hline Intercept & & 0.223 & 2.711 & 0.154 & 5.426 \\
\hline B.size & + & 0.000 & 0.121 & 0.000 & -0.147 \\
\hline B.independence & + & 0.234 & 3.674 & 0.270 & 8.839 \\
\hline CEO duality & - & -0.056 & -2.144 & -0.056 & -4.421 \\
\hline D.Own & - & 0.069 & 2.228 & -0.002 & -0.095 \\
\hline BL.Own & - & -0.218 & -7.040 & -0.086 & -4.595 \\
\hline C.Own & & -0.008 & -0.240 & -0.017 & -1.104 \\
\hline A.Com & & -0.024 & -1.547 & -0.005 & -0.614 \\
\hline Big-4 & & 0.050 & 3.279 & & \\
\hline LS & & -0.027 & -1.563 & & \\
\hline $\log$ size & & 0.001 & 0.176 & & \\
\hline Lev & & & & -0.002 & -1.386 \\
\hline Reserves & & & & 0.000 & -0.554 \\
\hline FNONF & & & & 0.035 & 3.150 \\
\hline Firm Fixed Effects & & & & & \\
\hline $\mathrm{N}$ & & 100 & & 100 & \\
\hline Adj. R2 & & $68.60 \%$ & & $87.40 \%$ & \\
\hline VIF (MAX) & & 3.39 & & 3.17 & \\
\hline
\end{tabular}


Corporate Governance Attributes, Corporate Risk Disclosure and Sustainability ...

In a nut shell, based on the above mentioned results I conclude refusing the alternative form of $\mathrm{H} 1$ and accepting the null form for the both dependent variables. Furthermore, accepting the alternative form of $\mathrm{H} 2 \& \mathrm{H} 3$ of my research and refusing the null form. For H4 I can accept the alternative form for the voluntary sustainability disclosure and refuse it for the risk disclosure. Moreover, my results support H5 by accepting the alternative form for the both dependent variables. But for the H6 \& H7 my results supported them by accepting the null form for the both dependent variables.

In relation to my control variables, never have I found any statistical significant variables except the big 4 audit firm for the dependent variable voluntary sustainability disclosure and the financing sector for the risk disclosure. The both have a positive signal which indicates that big 4 audit firm increase the level of sustainability disclosure and the financing sector lead to more increase in the risk disclosure level.

\section{9- Conclusion:}

In fact, the association between the corporate governance and the both voluntary sustainability and risk disclosure has been examined in the few last years, but the majority of these studies are non-related to the Egyptian environment, where a few studies related to the Egyptian environment were more concentrated on the disclosure level of corporate governance and these studies 
Corporate Governance Attributes, Corporate Risk Disclosure and Sustainability ...

don't include the sustainability index and risk disclosure, which ensures a gap must be filled.

In this regard, I try to fill this gap by analyzing the relationship between the corporate governance attributes and the both voluntary disclosure sustainability and risk in the Egyptian environment. In this paper I use a sample of 100 firm year observations which are included on the EGX100 index and I revealed a positive association between the board independence and the dependent variables risk and sustainability disclosure, and positive association between directors' ownership and the dependent variable sustainability disclosure without any effect on the risk disclosure. Moreover, I found a negative relationship between CEO duality and blockholder ownership as predictors and the dependent variables risk and sustainability disclosure. Furthermore, never have I found any relationship between the board size, ownership concentration and audit committee as predictors and the dependent variables risk and sustainability disclosure.

Actually, my study is limited by using the attributes of corporate governance that related to board of directors, ownership and the existence of audit committee without using other attribute related to the meetings of directors' board and audit committee and the audit committee size and so on. Furthermore, my study confined to the Egyptian environment only. 
Corporate Governance Attributes, Corporate Risk Disclosure and Sustainability ...

Dr/ Ahmed Mahmoud Ahmed Elbrashy

\section{References}

Abdallah, A., M. K. Hassan, P. L. McClelland, (2015), Islamic financial institutions, corporate governance, and corporate risk disclosure in Gulf Cooperation Council countries, Journal of Multinational Financial Management, Vol. 31, PP. 63-82.

Abraham, S., Cox, P., (2007). Analyzing the determinants of narrative risk information in UK FTSE 100 annual reports. Brit. Account. Rev. 39, 227-248

Adams, C. (2002), "Internal organisational factors influencing corporate social and ethical reporting: beyond current theorising", Accounting, Auditing \& Accountability Journal, Vol. 15 No. 2, pp. 223-250.

Adams, C. (2013), "Sustainability reporting and performance management in universities: challenges and benefts", Sustainability Accounting, Management and Policy Journal, Vol. 3 No. 3, pp. 384-392.

Adams, C. and Whelan, G. (2009), "Conceptualising future change in corporate sustainability reporting”, Accounting, Auditing \& Accountability Journal, Vol. 22 No. 1, pp. 118-143.

Adel, C., M. M. Hussain, E. K. Mohamed, M. A. Basuony, (2019), Is corporate governance relevant to the quality of corporate social responsibility disclosure in large European companies?, International Journal of Accounting \& Information Management, Vol. 27 No. 2, pp. 301-332.

Adnan, S. M., D. Hay, C. Staden, (2018), the influence of culture and corporate governance on corporate social responsibility disclosure: A cross country analysis, Journal of Cleaner Production, Vol. 198, PP. 820-832. 
Corporate Governance Attributes, Corporate Risk Disclosure and Sustainability ...

Dr/ Ahmed Mahmoud Ahmed Elbrashy

Al Farooque, O. and Ahulu, H. (2017), "Determinants of social and economic reportings: evidence from Australia, the UK and South African multinational enterprises", International Journal of Accounting and Information Management, Vol. 25 No. 2, pp. 177-200.

Amran, A., Devi, S.S., (2008). The impact of government and foreign affiliate corporate social reporting: the case of Malaysia. Manag. Audit J. 23 (No 4), 386-404.

Amran, A., Lee, S.P. and Devi, S.S. (2014), "The influence of governance structure and strategic corporate social responsibility toward sustainability reporting quality", Business Strategy and the Environment, Vol. 23 No. 4, pp. 217-235.

Amran, A., Rosli, A., Hassan, B., (2009). Risk reporting: an exploratory study on risk management disclosure in Malaysian annual reports. Manage. Audit. J. 24 (1), 39-57.

Arnold, M., Bassen, A. and Frank, R. (2012), "Integrating sustainability reports into financial statements: an experimental Study", Working Paper.

Azeem, M., Hassan, M. and Kouser, R. (2013), "Impact of quality corporate governance on firm performance: a ten year perspective", Pakistan Journal of Commerce and Social Sciences, Vol. 7 No. 3, pp. 656-670.

Barako, D. G., Hancock, P., \& Izan, H. Y. (2006). 'Relationship between corporate governance attributes and voluntary disclosures in annual reports: The Kenyan experience', Financial Reporting. Regulation and Governance, 5(1), 1-25.

Basuony, M., Elseidi, R. and Mohamed, E. (2014), "The impact of corporate social responsibility on firm performance: evidence form a mena 
Corporate Governance Attributes, Corporate Risk Disclosure and Sustainability ...

Dr/ Ahmed Mahmoud Ahmed Elbrashy

country", Corporate Ownership and Control, Vol. 12 No. 1, pp. 761-774.

Bradbury, M. E. (1990). The incentives for voluntary audit committee formation. Journal of Accounting and Public Policy, 9, 19-36

Burritt, R.L. and Schaltegger, S. (2010), "Sustainability accounting and reporting: fad or trend?", Accounting, Auditing \& Accountability Journal, Vol. 23 No. 7, pp. 829-846

Cabedo, J.D., Tirado, J.M., (2004). The disclosure of risk in financial statements. Account. Forum 28, 181-200.

Cebrián, G., Grace, M. and Humphris, D. (2013), “Organisational learning towards sustainability in higher education", Sustainability Accounting, Management and Policy Journal, Vol. 4 No. 3, pp. 385-306.

Chapple, W. and Moon, J. (2005), "Corporate social responsibility (CSR) in Asia: a seven-country study of CSR web site reporting", Business and Society, Vol. 44 No. 4, pp. 415-441

Chau, G. K., \& Gray, S. J. (2002). Ownership structure and corporate voluntary disclosure in Hong Kong and Singapore. The International Journal of Accounting, 37, 247-265.

Chau, G., \& Leung, P. (2006). The impact of board composition and family ownership on audit committee formation: Evidence from Hong Kong. Journal of International Accounting, Auditing and Taxation, 15, 1-15.

Chau, G.K., Gray, S.J., (2010). Family ownership, board independence and voluntary disclosure: evidence from Hong Kong. J. Int. Account. Audit. Taxat. 19 (No. 2), 93-109. 
Corporate Governance Attributes, Corporate Risk Disclosure and Sustainability ...

Dr/ Ahmed Mahmoud Ahmed Elbrashy

Cheng, E. C. M., \& Courtenay, S. M. (2006). Board composition, regulatory regime and voluntary Disclosure. International Journal of Accounting, 41(3), 262-289.

Collier, P. (1993). Factors affecting the formation of audit committees in major

listed companies. Accounting and Business Research, 23, 421430 .

Cooke, T. E. (1991). An assessment of voluntary disclosure in the annual reports of Japanese corporations. The International Journal of Accounting, 26(3), 174-189

Dharmadasa, P., Gamage, P. and Herath, S.K. (2014), "Corporate governance, board characteristics and firm performance: evidence from Sri Lanka", South Asian Journal of Management, Vol. 21 No. 1, pp. 7-31.

Donnelly, R., Mulcahy, M., (2008). Board structure, ownership, and voluntary

disclosure in Ireland. Corp. Govern. 16 (No. 5), 416-429.

Dyllick, T. and Hockerts, K. (2002), "Beyond the business case for corporate sustainability", Business Strategy and the Environment, Vol. 11 No. 2, pp. 130-141.

Eberhardt-Toth, E., (2017). Who should be on a board corporate social responsibility committee? J. Clean. Prod. 140, 1926-1935.

Elkelish, W., Hassan, M.K., (2014). Organizational culture and corporate risk disclosure: an empirical investigation for UAE listed companies. Int. J. Commer. Manage. 24 (4), 277-299

Eng, L. L., \& Mak, Y. T. (2003). 'Corporate governance and voluntary disclosure. Journal of Accounting and Public Policy, 22, 325345. 
Corporate Governance Attributes, Corporate Risk Disclosure and Sustainability ...

Dr/ Ahmed Mahmoud Ahmed Elbrashy

Evans, M. (2004). Board characteristics. Firm ownership and voluntary disclosureWorking Paper. Duke University: Fuqua School of Business.

Ezat, A., \& El-Masry, A. (2008). The impact of corporate governance on the timeliness of corporate internet reporting by Egyptian listed companies. Managerial Finance, 34(12), 848-867.

Forker, J. J. (1992). Corporate governance and disclosure quality. Accounting and Business Research, 22, 111-124.

Fuente, J.A., Garcia-Sanchez, I.M., Lozano, M.B., (2017). The role of the board of directors in the adoption of GRI guidelines for the disclosure of CSR information. J. Clean. Prod. 141, 737-750.

Gandía, J.L. (2008), "Determinants of internet-based corporate governance disclosure by spanish listed companies", Online Information Review, Vol. 32 No. 6, pp. 791-817.

Garcia-Meca and Sanchez-Ballestabes (2010). The association of board independence and ownership concentration with voluntary disclosure: A meta-analysis. The European Accounting Review, 19(3), 603-627.

Garcia-Torea, N., Fernandez-Feijoo, B. and de la Cuesta, M. (2016), "Board of director's effectiveness and the stakeholder perspective of corporate governance: do effective boards promote the interests of shareholders and stakeholders?", BRQ Business Research Quarterly, Vol. 19 No. 4, pp. 246-260.

Ghazali, N.A.M. (2007), "Ownership structure and corporate social responsibility disclosure: some Malaysian evidence", Corporate Governance: The International Journal of Business in Society, Vol. 7 No. 3, pp. 251-266. 
Corporate Governance Attributes, Corporate Risk Disclosure and Sustainability ...

Dr/ Ahmed Mahmoud Ahmed Elbrashy

Gibson, K. and O'Donovan, G. (2007), “Corporate governance and environmental reporting: an Australian study", Corporate Governance: An International Review, Vol. 15 No. 5, pp. 944956.

Gray, R. (2010), “A re-evaluation of social, environmental and sustainability accounting: an exploration of an emerging transdisciplinary feld?", Sustainability Accounting, Management and Policy Journal, Vol. 1 No. 1, pp. 11-32.

Guidry, R.P. and Patten, D.M. (2010), "Market reactions to the frst time issuance of corporate sustainability reports: evidence that quality matters", Sustainability Accounting, Management and Policy Journal, Vol. 1 No. 1, pp. 33-50.

Gul, F. A., \& Leung, S. (2004). Board leadership, outside directors' expertise and voluntary corporate disclosures. Journal of Accounting and Public Policy, 23, 1-2.

Hahn, R. and Kühnen, M. (2013), "Determinants of sustainability reporting: a review of results, trends, theory, and opportunities in an expanding feld of research", Journal of Cleaner Production, Vol. 59, pp. 5-21.

Haniffa, R. M., \& Cooke, T. E. (2002). Culture, corporate governance and disclosure in Malaysian corporations. Abacus, 38, 317-349.

Haniffa, R.M., Cooke, T.E., (2005). The impact of culture and governance on corporate social reporting. J. Account. Publ. Pol. 24, 391430.

Hashim, F., Mahadi, N.D., Amran, A., (2015). Corporate governance and sustainability practices in IsIamic financial institutions: the role of country of origin. J. Clean. Prod. 31, 36-43. 
Corporate Governance Attributes, Corporate Risk Disclosure and Sustainability ...

Dr/ Ahmed Mahmoud Ahmed Elbrashy

Hassan, M.K., (2009). UAE corporation-specific characteristics and level of risk disclosure. Manage. Audit. J. 24 (7), 668-687.

Hassan, M.K., (2014). Risk narrative disclosure strategies to enhance organizational legitimacy: evidence from UAE financial institutions. Int. J. Discl. Govern. 11 (1), 1-17.

Herzig, C. and Schaltegger, S. (2006), "Corporate sustainability reporting. an overview", in Schaltegger, S., Bennett, M. and Burrit, R. (Eds), Sustainability Accounting and Reporting, Springer, Dordrecht, pp. 301-324.

Ho, S. M. S., \& Wong, K. R. (2001). A study of the relationship between corporate governance structures and the extent of voluntary disclosure. Journal of International Accounting, Auditing and Taxation, 10, 139-156

Huafang, X., Jianguo, Y., (2007). Ownership structure, board composition and corporate voluntary disclosure: evidence from listed companies in

China.

Manag. Audit J. 22 (No. 6), 604-619.

Hussainey, K., \& Wang, M. (2010). Voluntary disclosure and corporate governance: Further UK evidence. Working paper. Stirling University.

Ibrahim, N., Howard, D. and Angelidis, J. (2003), "Board members in the service industry: an empirical examination of the relationship between corporate social responsibility orientation and directorial type", Journal of Business Ethics, Vol. 47 No. 4, pp. 393-401.

Jamali, D., Safieddine, A.M. and Rabbath, M. (2008), "Corporate governance and corporate social responsibility synergies and 
Corporate Governance Attributes, Corporate Risk Disclosure and Sustainability ...

Dr/ Ahmed Mahmoud Ahmed Elbrashy

interrelationships", Corporate Governance: An International Review, Vol. 16 No. 5, pp. 443-459.

Ji, X., Ahmed, K. and Lu, W. (2015), “The impact of corporate governance and ownership structure reforms on earnings quality in China", International Journal of Accounting and Information Management, Vol. 23 No. 2, pp. 169-198.

Jizi, M., Salama, A., Dixon, R. and Stratling, R. (2014), "Corporate governance and corporate social responsibility disclosure: evidence from the US banking sector", Journal of Business Ethics, Vol. 125 No. 4, pp. 601-615.

Jo, H., Harjoto, M.A., (2012). The causal effect of corporate governance on corporate social responsibility. J. Bus. Ethics 106 (1), 53-72.

Jorion, P., (2002). How informative are value at risk disclosures? Account. Rev. 77 (October (4)), 911-931.

Juhmani, O.I. (2013), "Ownership structure and corporate voluntary disclosure: evidence from Bahrain", International Journal of Accounting and Financial Reporting, Vol. 3 No. 2, p. 133.

Kabir, H. and Akinnusi, D.M. (2012), "Corporate social and environmental accounting information reporting practices in Swaziland", Social Responsibility Journal, Vol. 8 No. 2, pp. 156-173.

Klettner, A., Clarke, T. and Boersma, M. (2014), "The governance of corporate sustainability: empirical insights into the development, leadership and implementation of responsible business strategy", Journal of Business Ethics, Vol. 122 No. 1, pp. 145-165.

Kolk, A. (2003), "Trends in sustainability reporting by the fortune global 250", Business Strategy and the Environment, Vol. 12 No. 5, pp. 279-291. 
Corporate Governance Attributes, Corporate Risk Disclosure and Sustainability ...

Dr/ Ahmed Mahmoud Ahmed Elbrashy

Kolk, A. (2008), "Sustainability, accountability and corporate governance: exploring multinationals' reporting practices", Business Strategy and the Environment, Vol. 17 No. 1, pp. 1-15.

KPMG, (2005). International Survey of Corporate Responsibility Reporting. KPMG,

Amsterdam.

Lakhal, F. (2005). Voluntary earnings disclosures and corporate governance: Evidence from France. Review of Accounting and Finance, 4(3), 64-85

Laksmana, I. (2008). Corporate board governance and voluntary disclosure of executive compensation practices. Contemporary Accounting Research, 25(4), 47-82.

Lan, Y., Wang, L. and Zhang, X. (2013), "Determinants and features of voluntary disclosure in the chinese stock market", China Journal of Accounting Research, Vol. 6 No. 4, pp. 265-285.

Lau, C., Lu, Y. and Liang, Q. (2016), "Corporate social responsibility in China: a corporate governance approach", Journal of Business Ethics, Vol. 136 No. 1, pp. 73-87.

Leung, S., \& Horwitz, B. (2004). Director ownership and voluntary segment disclosure: Hong Kong evidence. Journal of International Financial Management and Accounting, 15, 235-260

Linsley, P.M., Lawrance, M.J., (2007). Risk reporting by largest UK companies: readability and lack of obfuscation. Account. Audit. Account. J. 20 (4), 620-627.

Linsley, P.M., Shrives, P.J., 2006. Risk reporting: a study of risk disclosure in the annual reports of UK companies. Brit. Account. Rev. 38 (1), 387-404. 
Corporate Governance Attributes, Corporate Risk Disclosure and Sustainability ...

Dr/ Ahmed Mahmoud Ahmed Elbrashy

Linsmeier, T.J., Thirnton, D.B., Venkatachalam, M., Welker, M., (2002). The effect of mandated risk disclosure on trading volume sensitivity to interest rate, exchange rate and commodity price movements. Account. Rev. 77 (2), 277-343.

Lopes, P.T., Rodrigues, L.L., (2007). Accounting for financial instruments: an analysis of the determinants of disclosure in the Portuguese stock exchange. Int. J. Account. 42, 25-56.

Lozano, R. and Huisingh, D. (2011), "Inter-linking issues and dimensions in sustainability reporting", Journal of Cleaner Production, Vol. 19 Nos 1/2, pp. 99-107.

Majumder, M.T.H., Akter, A. and Li, X. (2017), "Corporate governance and corporate social disclosures: a meta-analytical review", International Journal of Accounting and Information Management, Vol. 25 No. 4, pp. 434-458.

Malone, D., Fries, C., \& Jones, T. (1993). An empirical investigation of the extent of corporate financial disclosure in the Oil and Gas industry. No. 3. Journal of Accounting, Auditing and Finance, 8, 249-273.

Mangena, M., \& Tauringana, V. (2008). Audit committees and voluntary external auditor involvement in UK interim reporting. International Journal of Auditing, 12(1), 45-63.

Mann, M., Byun, S.E., Kim, H. and Hoggle, K. (2014), “Assessment of leading apparel specialty retailers' CSR practices as communicated on corporate websites: problems and opportunities", Journal of Business Ethics, Vol. 122 No. 4, pp. 599-622.

Marston, C., \& Polei, A. (2004). Corporate reporting on the internet by German companies". International Journal of Accounting Information Systems, 5, 285-311. 
Corporate Governance Attributes, Corporate Risk Disclosure and Sustainability ...

Dr/ Ahmed Mahmoud Ahmed Elbrashy

Mathews, M.R., (1995). Social and environmental accounting: a practical demonstration of ethical concern? J. Bus. Ethics 14 (8), 663671.

McKinnon, J. L., \& Dalimunthe, L. (1993). Voluntary disclosure of segment information by Australian diversified companies. Accounting and Finance, 33(1), 33-50.

Meier, H.H., Tomaszeweski, S.G., Tobing, R., (1995). Political risk assessment and disclosure in annual financial reports: the case of the Persian Gulf War. J. Int. Account. Audit. Tax. 4 (1), 49-68.

Michelon, G. and Parbonetti, A. (2012), "The effect of corporate governance on sustainability disclosure", Journal of Management \& Governance, Vol. 16 No. 3, pp. 477-509.

Mitchell, J. D., Chia, C. W. L., \& Loh, A. S. (1995). Voluntary disclosure of segment information: Further Australian evidence. Accounting and Finance, 35(2), 1-16.

Mohamed, E., Basuony, M. and Badawi, A. (2013), "The effect of corporate governance on firm performance in egyptian listed companies", Corporate Ownership and Control, Vol. 11 No. 1, pp. 691-705.

Mohamed, E., Basuony, M. and Hussain, M. (2017), "Dissemination of corporate information via social media and networks in africa", International Journal of Corporate Governance, Vol. 8 Nos 3/4, pp. 236-267.

Mohamed, E., Oyelere, P. and Jifri, K. (2009), "State corporate governance in Oman: progress has been rapid, sophistication has increased, but there is still room for improvement", Journal of Taxation and Regulation of Financial Institutions, Vol. 22 No. 4, pp. 3341. 
Corporate Governance Attributes, Corporate Risk Disclosure and Sustainability ... Dr/ Ahmed Mahmoud Ahmed Elbrashy

Mokhtar, E., Mellett, H., (2013). Competition, corporate governance, ownership structure and risk reporting. Manage. Audit. J. 29 (9), 838-865.

Mook, L. (2006), “Integrating and reporting an organisation's economic, social and environmental performance: the expanded value added statement", in Schaltegger, S., Bennett, M. and Burrit, R. (Eds), Sustainability Accounting and Reporting, Springer, Dordrecht, pp. 281-298.

Murphy, D. and McGrath, D. (2013), "ESG reporting - class actions, deterrence, and avoidance", Sustainability Accounting, Management and Policy Journal, Vol. 4, pp. 216-235.

Nagar, V., Nanda, D. and Wysocki, P. (2003), "Discretionary disclosure and stock-based incentives", Journal of Accounting and Economics, Vol. 34 Nos 1/3, pp. 283-309.

Nasir, N.M. and Abdullah, S.N. (2004), "Voluntary disclosure and corporate governance among financially distressed firms in Malaysia", Financial Reporting, Regulation and Governance, Vol. 3 No. 1, pp. 1-39.

Oliveira, J.S., Rodrigues, L.L., Craig, R., (2011). Voluntary risk reporting to enhance institutional and organizational legitimacy: evidence from Portuguese banks. J. Financ. Regul. Complian. 19 (3), 271-288.

Owen, D., (2007). Chronicles of wasted time? A personal reflection on the current

state of, and future prospects for, social and environmental accounting research.

Account Audit. Account. J. 21 (No. 2), 240-267. 
Corporate Governance Attributes, Corporate Risk Disclosure and Sustainability ...

Dr/ Ahmed Mahmoud Ahmed Elbrashy

Rajgopal, S., (1999). Early evidence on the informativeness of the SEC's market risk disclosures: the case of commodity price risk exposure of oil and gas producers. Account. Rev. July, 251-280.

Rao, K.K., Tilt, C.A. and Lester, L.H. (2012), "Corporate governance and environmental reporting: an Australian study", Corporate Governance, Vol. 12 No. 2, pp. 143-163.

Samaha, K. (2010). Do board independence and audit committees motivate disclosure on different corporate governance information categories in the annual reports in developing countries? International Research Journal of Finance and Economics, 57, 206-225.

Samaha, K., \& Dahawy, K. (2010). Factors influencing corporate disclosure transparency in the active share trading firms: An explanatory study. Research in Accounting in Emerging Economies, 10, 87118.

Samaha, K., \& Dahawy, K. (2011). An empirical analysis of corporate governance structures and voluntary corporate disclosure in volatile capital markets: The Egyptian experience. International Journal of Accounting, Auditing and Performance Evaluation, 7, 61-93 Nos. 1/2.

Samaha, K., K. Dahawy, K. Hussainey, P. Stapleton, (2012), The extent of corporate governance disclosure and its determinants in a developing market: The case of Egypt, Advances in Accounting, incorporating Advances in International Accounting, Vol. 28, PP. 168-178.

Sartawi, I.I.M., Hindawi, R.M., Bsoul, R. and Ali, A.E.J. (2014), "Board composition, firm characteristics, and voluntary disclosure: the case of jordanian firms listed on the amman stock exchange", International Business Research, Vol. 7 No. 6, p. 67. 
Corporate Governance Attributes, Corporate Risk Disclosure and Sustainability ...

Dr/ Ahmed Mahmoud Ahmed Elbrashy

Schadewitz, H. J., \& Blevins, D. R. (1998). Major determinants of interim disclosures in an emerging market. American Business Review, 16(1), 41-55.

Schaltegger, S. and Burritt, R. (2006), “Corporate sustainability accounting: a catchphrase for compliant corporations or a business decision support for sustainability leaders?", in Schaltegger, S., Bennett, M. and Burrit, R. (Eds), Sustainability Accounting and Reporting, Springer, Dordrecht, pp. 37-60.

Schaltegger, S. and Wagner, M. (2006a), "Managing sustainability performance measurement and reporting in an integrated manner: sustainability accounting as the link between the sustainability balanced scorecard and sustainability reporting", in Schaltegger, S., Bennett, M. and Burrit, R. (Eds), Sustainability Accounting and Reporting, Springer, Dordrecht, pp. 681-698.

Schaltegger, S. and Wagner, M. (2006b), "Integrative management of sustainability performance, measurement and reporting", International Journal of Accounting, Auditing and Performance Evaluation, Vol. 3 No. 1, pp. 1-19.

Schrand, C., (1997). The association between stock prices, interest rate sensitivity and disclosures about derivatives instruments. Account. Rev. January, 87-110.

Schrand, C., Elliott, J., (1998). Risk and financial reporting: a summary of the discussion at the 1997 AAA/FASB conference. Account. Horiz. September, 271-282.

Solomon, J., Solomon, A., Norton, S.D., Joseph, N.L., (2000). A conceptual framework for corporate risk disclosure emerging form the agenda for corporate governance reform. Brit. Account. Rev. 32 (December (4)), 337-478. 
Corporate Governance Attributes, Corporate Risk Disclosure and Sustainability ...

Dr/ Ahmed Mahmoud Ahmed Elbrashy

Spitzeck, H., (2009). The development of governance structures for corporate responsibility. Corp. Gov. Int. J. Bus. Soc. 9 (4), 495505.

Suchman, M.C., (1995). Managing legitimacy: strategic and institutional approaches. Manag. Rev. 20 (3), 571-610.

Tang, L., Gallagher, C.C. and Bie, B. (2015), "Corporate social responsibility communication through corporate websites: a comparison of leading corporations in the United States and China", International Journal of Business Communication, Vol. 52 No. 2, pp. 205-227.

The Egyptian Guide for Sustainability Reporting, 2016

Uddin, M.D., Hassan, M.K., (2011). Corporate risk information in annual reports and stock price behavior in the United Arab Emirates. Acad. Account. Financ. Stud. J. 15 (1), 59-84.

Webb, K.A., Cahan, S.F., Sun, J., (2008). The effect of globalization and legal environment on voluntary disclosure. Int. J. Account. 43 (No.3), 219-245.

Weir, C., \& Laing, D. (2003). Ownership structure, board composition and the market for corporate control in the UK: An empirical analysis. Applied Economics, 35, 1747-1759.

Willekens, M., Bauwhede, H. V., Gaeremynck, H. V., Ann, H. V., \& Gucht, L. V. D. (2005). The impact of internal and external governance mechanisms on the voluntary disclosure of financial and nonfinancial performance. BAA Auditing Research Conference. Birmingham (UK: Aston Business School).

Windolph, S.E., Schaltegger, S. and Herzig, C. (2014), "Implementing corporate sustainability: what drives the application of sustainability management tools in Germany?", Sustainability 
Corporate Governance Attributes, Corporate Risk Disclosure and Sustainability ... Dr/ Ahmed Mahmoud Ahmed Elbrashy

Accounting, Management and Policy Journal, Vol. 5 No. 4, pp. 378-404.

Wong, M., (2000). The association between SFAS no. 119 derivatives disclosures and foreign exchange risk exposure of manufacturing corporations. J. Account. Res. Autumn, 387-418.

World Commission on Environment and Development (Ed.) (1987), Our Common Future, Oxford University Press, Oxford. 
Corporate Governance Attributes, Corporate Risk Disclosure and Sustainability ... Dr/ Ahmed Mahmoud Ahmed Elbrashy

\section{Appendix A: Risk disclosure index}

\begin{tabular}{cc}
\hline Category & Disclosure Item \\
\hline Risk management \\
Objective of holding derivatives \\
Estimates \\
Collateral assets \\
Financial assets impairment \\
Accounting policies \\
Contingent liabilities \\
Contingent assets \\
Lower of cost or market \\
Contingency \\
\hline
\end{tabular}

Derivatives hedging

Hedging description

\begin{tabular}{ll} 
& Cash flow hedge \\
\hline Financial and other risks & Pricing risk \\
& Commodity \\
\hline ا العدد الثاني P. L & Liquidity
\end{tabular}


Corporate Governance Attributes, Corporate Risk Disclosure and Sustainability ... Dr/ Ahmed Mahmoud Ahmed Elbrashy

\section{Credit}

Capital adequacy

Changes in interest rates

Credit risk exposure

Operational risk

Insurance risk

Market risk

Interest rate

Exchange rate

Sensitivity analysis

Concentration of credit risk

Equity risk

Exchange rate

General risks information

Customer satisfaction

High competition

Natural disasters

Communications 
Corporate Governance Attributes, Corporate Risk Disclosure and Sustainability ... Dr/ Ahmed Mahmoud Ahmed Elbrashy

\begin{tabular}{cc}
\hline & Outsourcing \\
Reputation & Competition \\
Weather conditions \\
Change in technology \\
Dinancial instruments \\
Derivatives \\
Face value \\
Cumulative change in fair value \\
Reserves
\end{tabular}

Segment information

Geographical concentration

Customer concentration 
Corporate Governance Attributes, Corporate Risk Disclosure and Sustainability ...

\section{Appendix B: Sustainability disclosure index}

Category

Disclosure Item

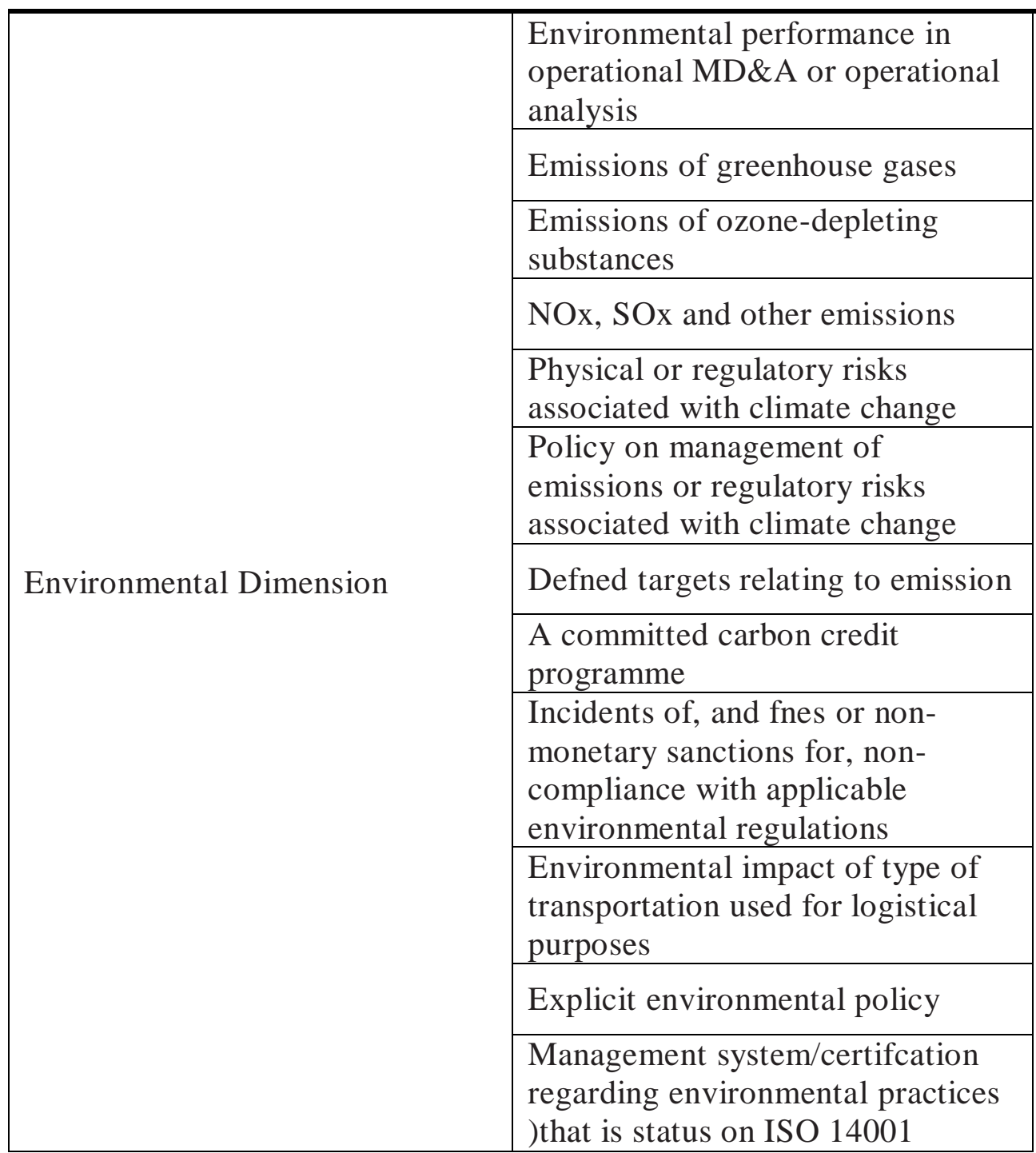


Corporate Governance Attributes, Corporate Risk Disclosure and Sustainability ...

Dr/ Ahmed Mahmoud Ahmed Elbrashy

\begin{tabular}{|c|c|}
\hline & certifcation( \\
\hline & $\begin{array}{l}\text { Efforts to preserve biodiversity } \\
\text { )e.g. plantation of tree( }\end{array}$ \\
\hline & $\begin{array}{l}\text { Policy/initiatives taken for } \\
\text { management of hazardous waste }\end{array}$ \\
\hline & $\begin{array}{l}\text { EMS in all location/ facilities and } \\
100 \% \text { ISO } 14001 \text { certifcation }\end{array}$ \\
\hline \multirow{11}{*}{ Social Dimension } & $\begin{array}{l}\text { Stated commitment to recognize } \\
\text { corporate responsibility standards }\end{array}$ \\
\hline & $\begin{array}{l}\text { CEO statement regarding } \\
\text { corporate responsibility/CSR }\end{array}$ \\
\hline & $\begin{array}{l}\text { Signatory to recognized global } \\
\text { CSR conventions )e.g. Global } \\
\text { Compact, Global Sullivan( }\end{array}$ \\
\hline & Publication of CSR report \\
\hline & $\begin{array}{l}\text { CSR report audited or } \\
\text { independently assured }\end{array}$ \\
\hline & $\begin{array}{l}\text { Social performance in operational } \\
\text { MD\&A or operational analysis }\end{array}$ \\
\hline & $\begin{array}{l}\text { Explicit policy/statement regarding } \\
\text { community investment }\end{array}$ \\
\hline & $\begin{array}{l}\text { Initiatives on community } \\
\text { awareness or education }\end{array}$ \\
\hline & $\begin{array}{l}\text { Company participation in public- } \\
\text { private initiatives for community } \\
\text { development }\end{array}$ \\
\hline & $\begin{array}{l}\text { Description/Amount of total } \\
\text { contributions/donations to } \\
\text { charitable initiatives )health, } \\
\text { education etc( }\end{array}$ \\
\hline & $\begin{array}{l}\text { Information on policy/rules } \\
\text { relating to non-fnancial benefts to }\end{array}$ \\
\hline
\end{tabular}


Corporate Governance Attributes, Corporate Risk Disclosure and Sustainability ...

Dr/ Ahmed Mahmoud Ahmed Elbrashy

employees )including housing etc.

Information on policy/rules

relating to healthcare

Policy/Rules relating to employee

separation and lay off

Policy/Rules for proft sharing

)stock options etc.( with lower

management/employee

Policy on code of conduct for

protecting human rights

Initiatives to enforce the above policy

Explicit health and safety policy

Policies/goals/initiatives on employee health and safety

Policy on discrimination in employment/treatment of employees affected with diseases

Policy/Rules to address incidence of sexual harassment and recourse

Policy on addressing rights of indigenous people affected by company operations

Information relating to product life cycle

Policy/procedures on recall of product

Policy/procedures on customer education regarding product/service provided

Policy/procedures for protection of customer confdentiality/privacy 
Corporate Governance Attributes, Corporate Risk Disclosure and Sustainability ...

Dr/ Ahmed Mahmoud Ahmed Elbrashy

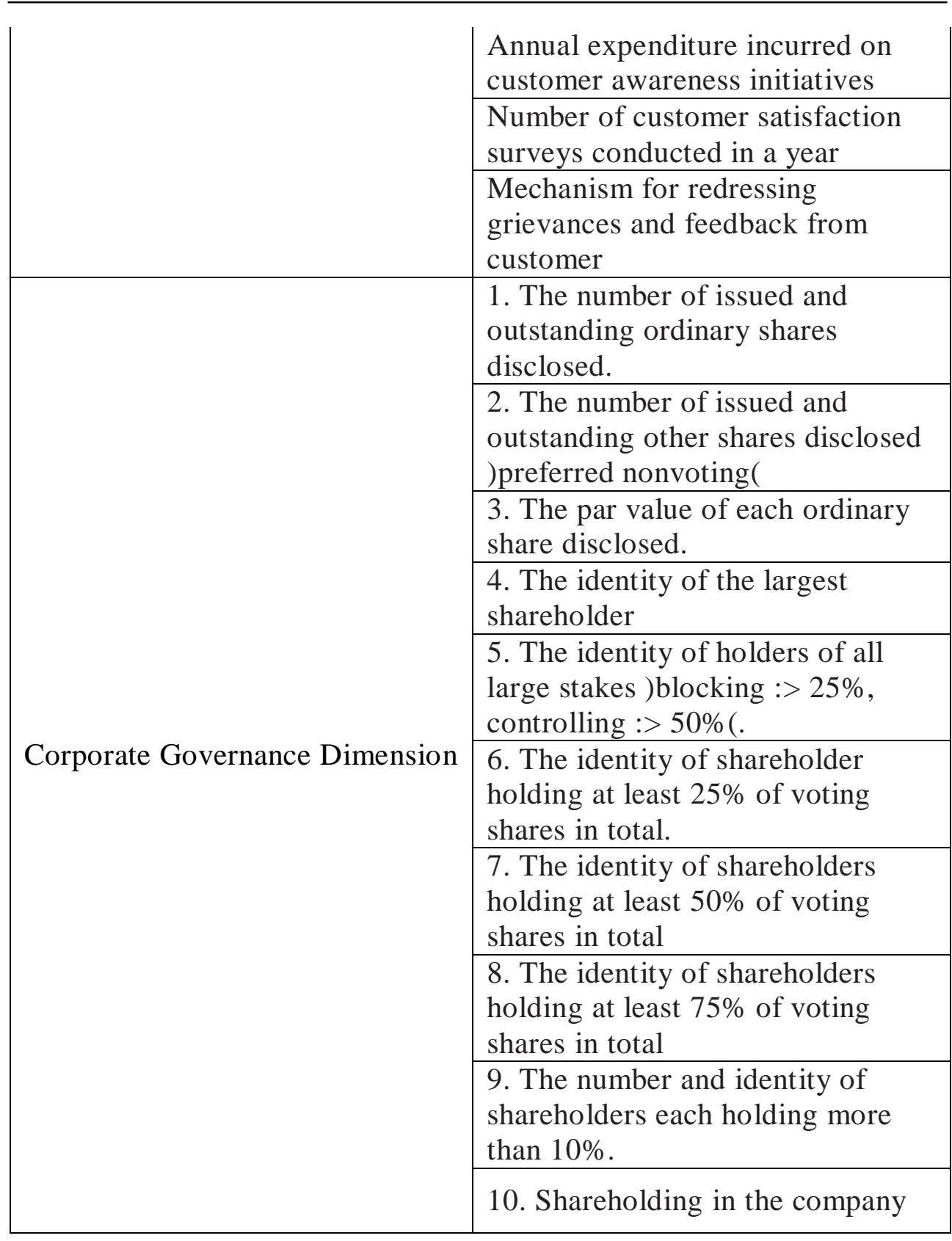


Corporate Governance Attributes, Corporate Risk Disclosure and Sustainability ...

Dr/ Ahmed Mahmoud Ahmed Elbrashy

by individual senior managers.

11. Shareholding in the company

by individual directors.

12. The description of share

classes provided.

13. A review of shareholder by type.

14. Cross-ownership.

15 . The contents of any corporate governance charter or code of best practices.

16. Existence of a Code of business conduct and ethics.

17. The contents of the Code of business conduct and ethics.

18. The changes in company's articles of association

19. The existence of voting rights for each voting or nonvoting share.

20. The transparency of the way that shareholders nominate directors to the board.

21 . The transparency of the way by which shareholders convene an extraordinary general meeting.

22. The transparency of the procedure for initiating inquires with the board.

23. The transparency of the procedure for putting forward proposals at shareholders meetings. 
Corporate Governance Attributes, Corporate Risk Disclosure and Sustainability ...

Dr/ Ahmed Mahmoud Ahmed Elbrashy

24. A formalized dividend policy

25. The existence of a review of

the last shareholders meeting.

26. Full general shareholders

meeting )GSM( minutes.

27. The existence of a calendar of important shareholders dates.

28. The company's accounting policy.

29. The accounting standards it uses for its accounts.

30. Whether the accounts meet local accounting standards.

31. Annual fnancial statements according to an internationally recognized accounting standard )IFRS/U.S. GAAP(.

32. Notes to annual fnancial statements according to IFRS/U.S. GAAP.

33. Independent auditors report with regard to annual fnancial statements according to IFRS/U.S. GAAP.

34. Unqualifed )clean( audit opinion with regard to annual fnancial statements according to IFRS/U.S. GAAP.

35. Disclosure of related party transactions )RPTs(: sales to/purchases from, payables to/receivables from related parties. 
Corporate Governance Attributes, Corporate Risk Disclosure and Sustainability ...

Dr/ Ahmed Mahmoud Ahmed Elbrashy

36. Indication that RPTs are made on market or non-market terms.

37. Interim )quarterly or

semiannual( fnancial statements

according to an internationally

recognized accounting

standard)IFRS/U.S. GAAP(.

38. Notes to such fnancial

statements.

39. Whether these fnancial

statements are audited or at least reviewed.

40. A basic earning forecast of any kind.

41. A detailed earnings forecast.

42. Financial information on a quarterly basis.

43. Segment analysis )results broken down by business line(.

44. Revenue structure )detailed breakdown(.

45. Cost structure )high degree of detail(.

46. The name of company's auditing frm.

47. A copy of the auditors report.

48. How much the company pays in audit fees to the auditor

49. Non-audit fees paid to the auditor.

50. Whether there are consolidated fnancial statements or whether 
Corporate Governance Attributes, Corporate Risk Disclosure and Sustainability ...

Dr/ Ahmed Mahmoud Ahmed Elbrashy

only the parent or holding company is audited.

51. Methods of asset valuation.

52. Information about the method of calculating fxed-asset depreciation.

53. A list of affliates in which the company holds a minority stake.

54. The ownership structures of affliates.

55. Details of the kind of business the company engages in.

56. Output in physical terms )values of sales for services sector companies(

57. Characteristics of fxed assets employed.

58. Effciency indicators.

59. Any industry-specifc ratios.

60. A discussion of corporate strategy.

61. Any plans for investment in the coming years.

62. Detailed information about investment plans in the coming years.

63. An output forecast of any kind.

64. An overview of trends in its industry. 
Corporate Governance Attributes, Corporate Risk Disclosure and Sustainability ...

Dr/ Ahmed Mahmoud Ahmed Elbrashy

65. The market share for any or all of the company's businesses.

66. The list of board members

)names(.

67. Details about directors other than name and title.

68. Details about other

employment and position of independent directors

69. Details about the directors' previous employment and positions.

70. When each director joined the board.

71. A named chairman listed.

72. Details about the chairman, other than name and title.

73. Details about role of the Board of Directors at the company.

74. A list of matters reserved for the board.

75. A list or board committees.

76. Names of all members of each existing committee.

77. Whether there are internal audit functions besides the Audit Committee.

78. Attendance record for board meetings.

79. The list of senior managers not on the Board of Directors. 
Corporate Governance Attributes, Corporate Risk Disclosure and Sustainability ...

Dr/ Ahmed Mahmoud Ahmed Elbrashy

80. The backgrounds of senior managers.

81. The non-fnancial details of the

CEO's contract.

82. The number of shares held in other affliated companies by managers.

83. The decision-making process for directors' pay.

84. The specifcs of directors' pay, including the salary levels.

85. The form of directors' salaries, such as whether they are in cash or shares.

86. The decision-making process for determining managerial )not board( pay.

87. The specifcs of senior management )not board( pay, such as salary levels and bonuses.

88. Performance related indicators guiding senior management compensation.

89. Policy and procedures on whistle blowing

90. Policy and procedures on insider trading

91. Contribution to political parties

93. Stated commitment to recognize corporate responsibility standards 
Corporate Governance Attributes, Corporate Risk Disclosure and Sustainability ... Dr/ Ahmed Mahmoud Ahmed Elbrashy

94. CEO statement regarding corporate governance

95. CEO statement regarding corporate responsibility/CSR

96. Signatory to recognized global

CSR conventions )e.g. Global

Compact, Global Sullivan(

97. Publication of CSR report

98. CSR report audited or independently assured

99. Report under GRI framework

100. Social and environmental performance in operational MD\&A or operational analysis 